\title{
Mast Cells Migrate from Blood to Brain
}

\author{
Ann-Judith Silverman, ${ }^{1}$ Anne K. Sutherland, ${ }^{2}$ Marta Wilhelm, ${ }^{2}$ and Rae Silver ${ }^{1,2,3}$ \\ ${ }^{1}$ Department of Anatomy and Cell Biology, College of Physicians and Surgeons, ${ }^{2}$ Department of Psychology, Columbia \\ University, New York, New York 10032, and 32Department of Psychology, Barnard College, New York, New York 10027
}

It is well established that mast cells (MCs) occur within the CNS of many species. Furthermore, their numbers can increase rapidly in adults in response to altered physiological conditions. In this study we found that early postpartum rats had significantly more mast cells in the thalamus than virgin controls. Evidence from semithin sections from these females suggested that mast cells were transiting across the medium-sized blood vessels. We hypothesized that the increases in mast cell number were caused by their migration into the neural parenchyma. To this end, we purified rat peritoneal mast cells, labeled them with the vital dyes PKH26 or CellTracker Green, and injected them into host animals. One hour after injection, dye-filled cells, containing either histamine or serotonin (mediators stored in mast cells), were located close to thalamic blood vessels. Injected cells represented $\sim 2-20 \%$ of the total mast cell population in this brain region. Scanning confocal microscopy con- firmed that the biogenic amine and the vital dye occurred in the same cell. To determine whether the donor mast cells were within the blood-brain barrier, we studied the localization of dye-marked donor cells and either Factor VIII, a component of endothelial basal laminae, or glial fibrillary acidic protein, the intermediate filament found in astrocytes. Serial section reconstructions of confocal images demonstrated that the mast cells were deep to the basal lamina, in nests of glial processes. This is the first demonstration that mast cells can rapidly penetrate brain blood vessels, and this may account for the rapid increases in mast cell populations after physiological manipulations.

Key words: mast cells; blood-brain barrier; hematopoietic system; basal lamina; GFAP; CellTracker green; vital dye; factor VIII; cell trafficking
Mast cells (MCs) occur in many organs and tissues, including the CNS of several species, including humans (Dropp, 1972, 1976; Theoharides, 1990), in which over a century ago Neumann identified them in brain infarcts and at the edge of multiple sclerosis plaques (Neumann, 1890). Animal experimentation has also implicated MCs in autoimmune demyelinating diseases (Powell et al., 1983; Seeldrayers et al., 1989; Brosnan et al., 1990) possibly through the capacity of their neutral proteases to degrade myelin. MCs degranulate in response to myelin basic protein and can induce peripheral (Johnson et al., 1988) and central (Theoharides et al., 1991) demyelination.

In the brains of normal mammals, MCs are located in the leptomeninges (Dropp, 1972, 1976; Theoharides, 1990) and are concentrated in the brain parenchyma along the blood vessels of several of the dorsal thalamic nuclei, (Goldschmidt et al., 1985). In the thalamus they are on the brain side of the blood-brain barrier (Dimitriadou et al., 1990; Manning et al., 1994). There are many mechanisms by which these multifaceted cells could influence the neural tissue around them. When MCs are triggered to degranulate, they undergo compound exocytosis, resulting in the

Received March 15, 1999; revised Sept. 27, 1999; accepted Oct. 14, 1999.

This work was supported by National Institute of Mental Health (NIMH) Grant 54088 (A.J.S.), National Science Foundation Special Grant for Experimental Research (A.J.S.), and NIMH Grant 29380 (R.S.). We thank Teresa Swayne for technical support with the confocal microscope and Kata Pula and Darrell Silver for assistance with the photomicrographs. Mr. Peter Carolan (Columbia University) and Jason Ho (Caltech) performed the immunoselections. The confocal microscope facility was established by a National Institutes of Health (NIH) Shared Instrumentation Grant 1S10 RR10506 and is supported by NIH Grant 5 P30 CA13696 as part of the Herbert Irving Cancer Center at Columbia University, New York, NY 10032.

Correspondence should be addressed to Ann-Judith Silverman, Department of Anatomy and Cell Biology, College of Physicians and Surgeons, Columbia University, 630 West 168th Street, New York, NY 10032. E-mail: AS36@columbia.edu. Copyright (C) 1999 Society for Neuroscience $0270-6474 / 00 / 200401-08 \$ 15.00 / 0$ release of the internal contents of their secretory granules (Kaminer et al., 1995; Guo et al., 1998). Brain MCs increase their secretory activity under normal physiological conditions, including exposure of the animal to gonadal steroid levels associated with reproduction (Silver et al., 1996; M. Wilhelm, B. King, A. J. Silverman, R. Silver, unpublished observations). MCs contain stored mediators such as biogenic amines, and in rats it has been reported that $90 \%$ of the thalamic histamine is attributable to the presence of these cells (Goldschmidt et al., 1985). Rat MCs contain or can make on activation a wide variety of bioactive molecules including neuropeptides (Cutz et al., 1978; Yano et al., 1989), neurotransmitters such as 5HT, nitric oxide (Salvemini et al., 1990; Bacci et al., 1994), and ATP (Osipchuk and Cahalan, 1992), and neuromodulators such as prostaglandin D2 (LeviSchaffer and Shalit, 1989; Urade et al., 1990). They can produce growth factors, including NGF (Leon et al., 1994) and LIF (Marshall et al., 1993), a known cholinergic differentiation factor. Isolated brain MCs secrete histamine and TNF- $\alpha$ (Cocchiara et al., 1999). Some of these compounds could alter the properties of the blood-brain barrier (Zhuang et al., 1996) as well as modulate neuronal targets. For example, ganglion cells derived from animals made hyperallergic show many changes in excitability, including membrane depolarization and altered resting membrane conductance (Undem et al., 1995) compared with controls. These alterations are attributable to the acquisition of sensitivity to substance P (Weinrich et al., 1997).

Given the wide-ranging secretory capability of MCs, our interest lies in the mechanisms by which the size of the MC population in the CNS is regulated. Changes in brain MC numbers have been described during development in mammalian and avian species (Dropp, 1972; Lambracht-Hall et al., 1990; Gill and Riss- 
man, 1998; Zhuang et al., 1999). In doves, a 10-fold increase in brain MCs occurs rapidly, within 1-2 $\mathrm{hr}$ of pairing with a mate (Zhuang et al., 1993). In this species MCs are concentrated in the medial habenula of the epithalamus, an integrative center between the limbic forebrain and midbrain (Sutherland, 1982). The phenotype of these cells suggests that they are mature (Zhuang et al., 1993; Silverman et al., 1994), but their source is unknown. In mammals, increases in brain MC numbers occur in hibernation versus awake states in the hedgehog (Flood and Kruger, 1970), whereas their numbers decline in response to stress (Theoharides et al., 1995) or handling in rats (Persinger, 1983). These declines are usually interpreted to reflect loss of granular contents rather than changes in absolute numbers of cells (Hebda et al., 1993).

In adult animals, MCs accumulate at sites of angiogenesis and tissue damage (Gruber and Kaplan, 1993; Hebda et al., 1993; Bankl et al., 1995). It is well known from in vitro studies that mature MCs can adhere to extracellular matrix materials such as laminin (Thompson et al., 1990) and can migrate in response to FceRI-mediated activation on laminin, fibronectin, and matrigel (Thompson et al., 1993). Cytokine-stimulated directional movement using a Boyden chamber reveals that rapid variations in MC shape coincide with this movement (Gruber et al., 1994).

Although it is generally accepted that MCs circulate as committed precursors rather than as mature cells (Galli et al., 1993; Kitamura et al., 1993), the rate of increase of a mature MC population in the adult brain suggests the possibility that mature MCs translocate from extraneural sources into the CNS. To test the hypothesis that MCs might enter the brain via the blood supply, we purified adult rat peritoneal MCs, labeled them ex vivo with a vital dye, and searched for them in the CNS after intravascular injection into a host animal.

\section{MATERIALS AND METHODS}

\section{Animals}

Subjects were female Wistar rats, 200-250 gm (Charles River, Kingston, NY), either virgins or newly parturient animals that had given birth 1-4 $\mathrm{d}$ earlier and whose pups were removed as part of a different study. Animals were maintained on a $12 \mathrm{hr}$ light/dark cycle. Virgin animals were housed two to a cage; postpartum animals remained in their home cage after removal of the pups. All animals were provided with food and water ad libitum.

To examine the effect of physiological state on MC numbers, virgin $(n=10)$ and $4 \mathrm{~d}$ postpartum $(n=10)$ animals were prepared for quantitative analysis using acidic toluidine blue metachromasia as an MC marker (see below). In all subsequent studies, postpartum animals were used. To determine whether MCs migrate into the brain, animals that served as recipients of dye-labeled cells $(n=15)$ were each given MCs from a separate donor. To assess the proportion of MCs that was derived from donor cells, dye-labeled (CellTracker Green; CTG) MCs were injected, and tissue from host animals ( $n=6$; six donors) was prepared for immunocytochemistry with serotonin as the MC marker (see below). Tissue from two additional animals was prepared for embedding in EPON and preparation of $1 \mu \mathrm{m}$ sections. Animals $(n=4)$ were used in tests of various fixatives for autofluorescence (see below).

\section{Surgery}

All animals were deeply anesthetized with sodium pentobarbital (60 $\mathrm{mg} / \mathrm{kg}$, i.p.) before surgery, and donor/host pairs remained under anesthesia throughout the entire experiment. When spinal reflexes were absent, a longitudinal incision was made in the abdominal wall. After removal of the peritoneal fluid (see Mast cell isolation), the animal was euthanized. Cells were injected into the host via the carotid artery $(n=$ $6)$ or jugular vein $(n=9)$ with identical results. The quantitative analysis was derived from additional animals ( $n=6$ hosts, $n=6$ donors) that received cells via the jugular. The survival period of the host after injection of donor MCs was $1 \mathrm{hr}$. The animals were then perfused transcardially with fixative (see below).

For preparation of the plastic embedded tissue, animals were given an overdose of sodium pentobarbital $(100 \mathrm{mg} / \mathrm{kg})$ and perf used with fixative (see below).

The housing, care, and experimental procedures (for both the adults and pups) were approved by the Institutional Animal Care and Use Committee of Columbia University and met National Institutes of Health standards.

\section{Mast cell isolation I}

MCs were isolated by two different methods. In the first $(n=2)$ the protocol of Purcell was followed (Purcell et al., 1989). In brief, $20 \mathrm{ml}$ of MC media $\left[\mathrm{NaCl} 150 \mathrm{~mm}, \mathrm{KCl} 3.7 \mathrm{mM}, \mathrm{Na}_{2} \mathrm{HPO}_{4} 3 \mathrm{~mm}\right.$, dextrose $5.6 \mathrm{~mm}$, $\mathrm{CaCl}_{2} 0.9 \mathrm{~mm}, 0.1 \%$ BSA (Fraction V, Sigma, St. Louis, MO), 0.1\% gelatin (Purified Grade, Fisher Scientific, Pittsburgh, PA), 200 U/100 ml heparin (Grade 1-A, Sigma), and wortmannin (from Penicillium fumiculosum, Sigma) $1 \mathrm{~nm}$ (Marquardt et al. (1996)] to stabilize the cells during isolation was infused at room temperature into the abdominal cavity, and the abdomen was massaged $\sim 50$ times. Wortmannin was kept in the MC media (MCM) solution until the final washes after vital dye staining and before cell infusion. The peritoneal fluid was recovered into a $50 \mathrm{ml}$ Falcon tube (Fisher, Polypropylene) and centrifuged (Beckman model TJ-6, Beckman, Palo Alto, CA) at $100 \times g, 7 \mathrm{~min}, 4^{\circ} \mathrm{C}$. the supernatant was discarded, and the pellet (cells) were resuspended in $\sim 1 \mathrm{ml}$ of MCM to make a total volume of $2 \mathrm{ml}$. This was layered on top of $4 \mathrm{ml}$ of a $38 \%$ BSA solution (Purcell et al., 1989) in a $15 \mathrm{ml}$ conical Falcon tube, allowed to equilibrate on ice for $30 \mathrm{~min}$, and centrifuged at $1400 \times g$ for $30 \mathrm{~min}$ at $4^{\circ} \mathrm{C}$. MCs entered the BSA, and the red blood cells and leukocytes remained at the interface of the BSA and MCM. This interface was washed twice with MCM. The BSA was transferred to a $50 \mathrm{ml}$ Falcon tube, and MCM was added to a final volume of $50 \mathrm{ml}$. After centrifugation (at $100 \times g$ for $10 \mathrm{~min}$ ), the cellular pellet was washed three times in $\operatorname{MCM}(5 \mathrm{ml}, 100 \times g)$.

\section{Mast cell isolation II}

In the second method $(n=4)$ Tyrodes buffer (Sigma) was used for the peritoneal flush, and the cells were subjected to immunoselection using $50 \mathrm{~nm}$ magnetic beads (Miltenyi Biotec, Auburn, CA) covalently coupled to goat anti-mouse IgG. The cells recovered in the flush were incubated for $1 \mathrm{hr}$ at $4^{\circ} \mathrm{C}$ with mouse IgG anti-rat CD45 (R\&D Systems, Minneapolis, MN) at a concentration of $2 \mu \mathrm{g} / 10^{6}$ cells. After washes in $5 \mathrm{ml}$ RPMI 1640 supplemented with 2-mercaptoethanol and penicillin-streptomycin (RPMI-O; Life Technologies, Gaithersburg, MD), the sodium azide in which the beads are supplied must be removed and the solution sterilized. First, $275 \mu \mathrm{l}$ of the bead solution is passaged through a Millex GV filter (Millipore Corporation, Bedford, MA) and stored in a microfuge tube on ice. The magnetic immunoselection column (Miltenyi Biotec) is attached to the magnetic stand (Miltenyi Biotec) and rinsed with $500 \mu \mathrm{l}$ of PBS supplemented with $0.5 \% \mathrm{w} / \mathrm{v}$ BSA (Life Technologies). The beads are passed through the column and adhere while the column remains fixed on the magnet. Beads are washed two times with $500 \mu \mathrm{l} \mathrm{PBS} / \mathrm{BSA}$. Removal of the column from the magnetic stand followed by a wash with $200 \mu \mathrm{l}$ PBS/BSA results in the yellow-brown microbead effluent. This is collected and stored at $4^{\circ} \mathrm{C}$.

The peritoneal cells are suspended in $100 \mu$ l of RPMI-O. Eighty microliters of this suspension are incubated with $20 \mu \mathrm{l}$ of the beads for 15 min at $4^{\circ} \mathrm{C}$ immediately before immunoselection. For cell purification a new column is rinsed with $500 \mu \mathrm{l}$ RPMI-O, and the cells, coupled to beads, are then passed through it. The column is rinsed three times with $500 \mu$ l RPMI-O to clear the non-CD45 cells or debris. The column is then removed from the magnet, and an additional $1 \mathrm{ml}$ of RPMI-FCS is used to push the magnetic bead/cells from the side of the column. This resulted in the isolation of $10^{5}$ cells/animal with $\sim 95 \%$ viability as assessed by trypan blue exclusion.

The purified cells were placed in suspension culture for $24 \mathrm{hr}$ in RPMI-O + 10\%FCS in 24-well Falcon plates using $100 \mathrm{ng} / \mathrm{ml}$ stem cell factor (R\&D Systems). In this way any macrophages/monocytes that had also been selected attach to the surface of the culture dish, and the MCs remain in solution.

Identification of MC phenotype (from the density gradient purification) was made on aliquots of cells from the final pellet. Peritoneal MCs are known to be metachromatic to acidic toluidine blue, to contain proteoglycans that react predominately with safranin after alcian blue histochemistry (Enerback et al., 1986), and to express the c-kit receptor (Tsai et al., 1991; Katayama et al., 1993; Rodewald et al., 1996). The isolated MCs described here met all of those criteria. To identify the c-kit receptor we used immunocytochemistry and an antibody to the 
C-terminal of the protein (Santa Cruz Biotechnologies, Santa Cruz, CA; see below for method). It should be noted that brain MCs are phenotypically more similar to connective tissue MCs than they are to those from the gut mucosa (for review, see Silver et al., 1996). For those MCs isolated by immunoselection, identification of the cells was performed after $1 \mathrm{~d}$ in culture (i.e., just before injection) using acidic toluidine blue staining only.

\section{Vital dyes}

PKH26 (PKH26-GL cell linker kit; Sigma). PKH26 is an aliphatic reporter molecule that inserts into the cell's plasma membrane. Its fluorescent peak is $567 \lambda$. Use of this dye can be combined with immunocytochemistry (see below). Labeling was performed according to the directions provided by the supplier. The final pellet of MCs, with sufficient medium to just cover the cells, was suspended in $1 \mathrm{ml}$ of Diluant $\mathrm{C}$ (Sigma) followed by $1 \mathrm{ml}$ of $10^{-6} \mathrm{M}$ PKH26 in the same solution. The cells were incubated at room temperature for $5 \mathrm{~min}$ and then an equal volume of normal rat serum (Life Technologies, Grand Island, NJ) was added and incubation continued for $1 \mathrm{~min}$. At the end of this period, MCM $(4 \mathrm{ml})$ was added to the test tube, and the cells were centrif uged at $400 \times g$ for $10 \mathrm{~min}$. The pellet was washed three times in $\sim 5 \mathrm{ml} \mathrm{MCM}$ without wortmannin and centrifuged after each wash for $10 \mathrm{~min}$ at $400 \times$ g. At this point, the cells were resuspended in $0.9 \%$ saline for injection into the host.

CellTracker green. 5-Chloromethylfluorescein diacetate (CTG; Molecular Probes, Eugene, OR) enters the cell and is then cleaved by cytoplasmic esterases to form a fluorescent molecule, which has an emission peak of $520 \lambda$. Glutathione $S$-transferase attaches the fluorophore to the tripeptide glutathione, thereby trapping the dye within the cell. CTG is compatible with immunocytochemistry and was superior to the PKH26 in that it remained cell-associated longer with a stronger signal.

For isolation procedure I, MCs in the final pellet were resuspended in $\sim 2 \mathrm{ml}$ of MCM to which $8 \mathrm{ml}$ of CTG was added to a final concentration of the dye of $1 \mathrm{~nm}$. Cells were incubated in this solution for $45 \mathrm{~min}$ at $37^{\circ} \mathrm{C}\left(95 \% \mathrm{O}_{2}, 5 \% \mathrm{CO}_{2}\right)$ and then concentrated and incubated for an additional $30 \mathrm{~min}$ in MCM without CTG. This last step ensures that the cellular esterases complete the necessary chloromethyl and acetate modifications. The final washes were without wortmannin. This procedure was used for all experiments except for four of the six animals used to estimate the donor contribution to the total size of the MC population.

For isolation procedure II, MCs were harvested from the cultures, pelleted, and resuspended in $2 \mathrm{ml}$ of RPMI-O, and the labeling was performed as above. Cells isolated by immunoselection were more brightly labeled with CTG.

\section{Injection of cells}

Recipients were inf used over a 5 min period using a 27 gauge needle with $\sim 0.5 \mathrm{ml}$ of final suspension media estimated to contain $2.5 \times 10^{5} \mathrm{MCs}$.

\section{Mast cell and blood-brain barrier markers}

The presence of CTG identified the donor MCs. The boundaries of the blood-brain barrier were determined in two ways: by the localization of Factor VIII and of glial fibrillary acidic protein (GFAP). The former is a procoagulent protein produced by endothelial cells and forms a component of the extracellular matrix beneath the endothelium; it is secreted as mature light and heavy chains and deposited as irregular diffuse puncta (Miyagami et al., 1987). In the presence of von Willebrand's factor, Factor VIII forms a stable complex (Kaufman et al., 1988). The immunodetection of this molecule then serves to mark the brain side of the blood vessel. GFAP is the intermediate filament of fibrillary astrocytes in the CNS, the processes of which make a perivascular sheath around blood vessels and thereby contribute to the blood-brain barrier. These processes are internal to Factor VIII, i.e., on the brain side.

\section{Tissue preparation}

Animals that received $\mathrm{PKH} 26$-labeled cells were perfused with $4 \%$ carbodiimide (Sigma) in $0.1 \mathrm{M}$ phosphate buffer at $\mathrm{pH} 7.4$ (PB), the only fixative compatible for histamine immunocytochemistry (Airaksinen and Panula, 1988). Those receiving CTG-labeled cells were perfused first with $200 \mathrm{ml}$ of $2 \%$ paraformaldehyde containing $5 \mathrm{~mm}$ EGTA, $2 \mathrm{~mm}$ $\mathrm{MgCl}_{2}$ in $0.1 \mathrm{M} \mathrm{PB}, \mathrm{pH} 7.4$, followed by $200 \mathrm{ml} 2 \%$ paraformaldehyde in $100 \mathrm{~mm} \mathrm{NaB} \mathrm{O}_{7}, \mathrm{pH} 11$ (Bacallao et al., 1995). This protocol was compatible with immunocytochemistry for serotonin, Factor VIII, and GFAP. This fixative reduced background fluorescence. The fixative used to quantify the number of toluidine blue-positive MCs was $4 \%$ paraformaldehyde. Finally, for tissue embedded in EPON, animals were perfused at $37^{\circ} \mathrm{C}$ with a pre-fix of oxygenated Ringer's solution containing $0.5 \%$ tannic acid followed by the fixative $1 \%$ paraformaldehyde $/ 3 \%$ glutaraldehyde (Buma and Roubos, 1986).

After fixation, $50 \mu \mathrm{m}$ sections were cut on a vibratome (Microslicer 1500E; Ted Pella Inc., Redding, CA) (carbodiimide-fixed) or freezing microtome (Bausch \& Lomb, Rochester, NY) (aldehyde-fixed). For analysis of mast cell number in virgin versus postpartum animals, sections were mounted on glass slides, dried, and stained with acidic toluidine blue $[4 \mathrm{mg} / \mathrm{ml}$ toluidine blue $\mathrm{O}$ (Sigma) dissolved in $60 \%$ ethyl

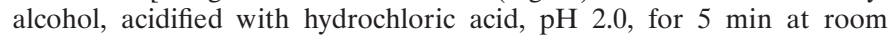
temperature, dehydrated through graded alcohols, cleared in Histoclear (Fisher Scientific), and coverslipped with Permount (Fisher Scientific)]. Immunocytochemistry was performed by incubation in polyclonal antisera to histamine (1:2000; IncStar, Stillwater, CA), serotonin $(1: 10,000$; IncStar), Factor VIII (1:400; Dako, Carpinteria, CA), or GFAP (1:1000; Boehringer Mannheim, Indianapolis, IN). Antigen-antibody complexes were identified by the sequential exposure to goat anti-rabbit IgG conjugated to biotin (Vector, Burlingame, VT), avidin-FITC (Vector, histamine), avidin-Texas Red (Vector, serotonin), or goat anti-rabbit Alexa 567 (Molecular Probes; serotonin, Factor VIII, GFAP). PB containing $0.1 \%$ Triton $\mathrm{X}-100$ with $3 \%$ normal goat serum was used before exposure to antiserum, and $\mathrm{PB}$ without detergent was used to dilute the antiserum. For the c-kit staining referred to above, an avidin-biotin-HRP complex (Vector) was used, and the enzyme was detected with the Vector SG reagent.

Sections were examined on a conventional/fluorescent microscope (Olympus, New York/New Jersey Scientific Inc., Middlebush, NJ; Nikon Eclipse, Nikon, Inc. Distribution Group, Melville, NJ) or with a scanning confocal microscope (Zeiss, Inc., Thornwood, NJ) using LSM 410. Images were acquired using 16 averaged line scans at $1028 \times 1028$ pixel resolution and printed using Adobe PhotoShop 4.

\section{Controls}

The first control determined whether any of the vital dye signal was caused by autofluorescence. Animals received no cells but were perfused with carbodiimide $(n=1)$ or with paraformaldehyde with the $\mathrm{pH}$ shift protocol described above $(n=3)$. After immunocytochemistry for histamine (FITC) or serotonin (Texas Red), respectively, tissue sections of the thalamus were examined. For each amine, resident MCs could be found using conventional and confocal microscope. These cells did not fluoresce when excited at wavelengths other than that of their specific fluorophore. A class of autofluorescent cells was observed. Confocal analysis demonstrated that they had exceptionally large granules (compared with MCs) that were more widely spaced within the cytoplasm, whereas those of MCs are densely packed. They were not immunoreactive for 5HT or histamine. These cells were excluded from our analyses and may represent neurolipomastocytes (Ibrahim et al., 1979).

The second control focused on the possibility that the vital dye had entered the circulation and resident MCs had absorbed this material from the vasculature. Animals $(n=2)$ were infused with $0.5 \mathrm{ml} \mathrm{CTG} \mathrm{(1}$ $\mathrm{nM}$ ) in mast cell media via the carotid artery. One hour after inf usion, the animals were perfused with the paraformaldehyde fixative, and immunocytochemistry for serotonin was performed on thalamic sections. MCs could be identified by the presence of the amine; none contained CTG. This was confirmed using the confocal microscope (data not shown).

\section{Semithin sections}

After perfusion, fixation, and sectioning on the vibratome, regions of the dorsal thalamus were microdissected and post-fixed with $2 \% \mathrm{OsO}_{4}$ in $0.9 \% \mathrm{NaCl}$ containing $1.5 \% \mathrm{~K}_{3} \mathrm{Fe}(\mathrm{CN})_{6}$ (Sigma) for $1 \mathrm{hr}$. Tissue was dehydrated through propylene oxide and flat-embedded in EPON, and 1 $\mu \mathrm{m}$ sections were cut using a diamond knife, dried on glass slides, and stained with basic toluidine blue (borate buffer, $\mathrm{pH}$ 11).

\section{Cell counts}

For determining the relative numbers of MCs in virgin versus postpartum animals, cell counts were performed on alternate $50 \mu \mathrm{m}$ sections stained with acidic toluidine blue. Sections were collected serially and mounted onto glass slides. Thalamic MCs were counted in 10 alternate serial sections from the level of the medial habenula and proceeding caudalward for a total of $1 \mathrm{~mm}$. Cell number was determined using a modified optical dissector method, an unbiased stereological approach that is particularly appropriate for thick sections and obviates the need 
for assumptions, such as uniform nuclear size or orientation of MCs between the two conditions (for review, see West et al., 1991; Coggeshall and Lekan, 1996). In the tissue examined, there were three distinct focal planes, and an MC nucleus (the "profile") was in crisp focus in only one of them. Because MCs are not tightly clustered (unlike neurons in a particular nucleus or layer), it is easy to distinguish nuclear and/or cellular outlines between one cell and its neighbor (should it have any). We counted nuclei in each of these three planes, and to avoid double counting nuclei that were on the top or bottom planes, we used only alternate sections. Counting nuclei in only one plane results in underestimating the $\mathrm{MC}$ population so that the phenomenon is not as robust as it is. The counts reported here were made by A.K.S.; six birds (three virgin, three postpartum) were recounted (by A.J.S.), and there was $>90 \%$ agreement.

To estimate the contribution of vital dye-labeled MCs to the total population, animals were injected with dye-labeled cells, and $1 \mathrm{hr}$ later tissue was prepared for serotonin immunofluorescence to identify all MCs. Serotonin-positive mast cells were counted in every third $50 \mu \mathrm{m}$ section from the level of the medial habenula (as above) for a total of 10 sections per animal. Each cell was checked to determine whether it contained CTG. Because the mean mast cell diameter is $\sim 8-10 \mu \mathrm{m}$, no correction factor was applied.

\section{RESULTS}

\section{General observations}

In the adult rat brain, MCs are concentrated in the thalamus (Dropp, 1972; Ibrahim, 1974) on the brain side of the blood-brain barrier (Dimitriadou et al., 1990; Manning et al., 1994). In semithin sections taken from non-injected animals, MCs filled with secretory granules were present along the walls of medium-sized blood vessels in the dorsal thalamus. Elongate cells, with one pole in the neuropil and the other either embedded in the basal lamina of the endothelial cell or between the endothelial cell and the pericyte, were found (Fig. $1 A-C$ ).

MCs immunoreactive for either histamine or serotonin were easy to distinguish from neurons by their round or (rarely) elongate shapes, the absence of axonal or dendritic processes, and the abundance of regularly shaped cytoplasmic granules. There were no histaminergic or serotoninergic neurons in the area examined. In the sections studied, both dye-filled and endogenous MCs were restricted to the thalamus and absent from cortical, subcortical, and other diencephalic regions. This observation underscores the specificity of the phenomenon.

\section{Physiological state of animals}

Newly postpartum rats had significantly more toluidine bluepositive MCs in the thalamus than did virgin, age- and weightmatched controls $(2576.5+463$ vs $1268.1+300 ; p=0.034)$. All experiments reported below used postpartum animals.

\section{Confocal microscopy}

Vital dye and amine in a single cell

Double-labeled MCs were found using both PKH26/histamine and $\mathrm{CTG} /$ serotonin combinations by conventional fluorescent microscopy (data not shown) and confocal microscopy. Examination of $1 \mu \mathrm{m}$ optical slices confirmed the presence of both dye and amine within the same cell (Fig. $2 A-C$ ). The CTG label filled the cytoplasm, making it a superior marker (Fig. $2 A$ ). In contrast, PKH26 was frequently sequestered to one pole (data not shown). The immunofluorescent signal for the amines was clearly granular (Fig. 2B,C).

\section{Numbers of donor cells in the thalamus}

At low magnification (Fig. $3 A$ ), serotonin-positive mast cells are seen distributed throughout the dorsal thalamus in association with blood vessels as previously reported (see introductory re-

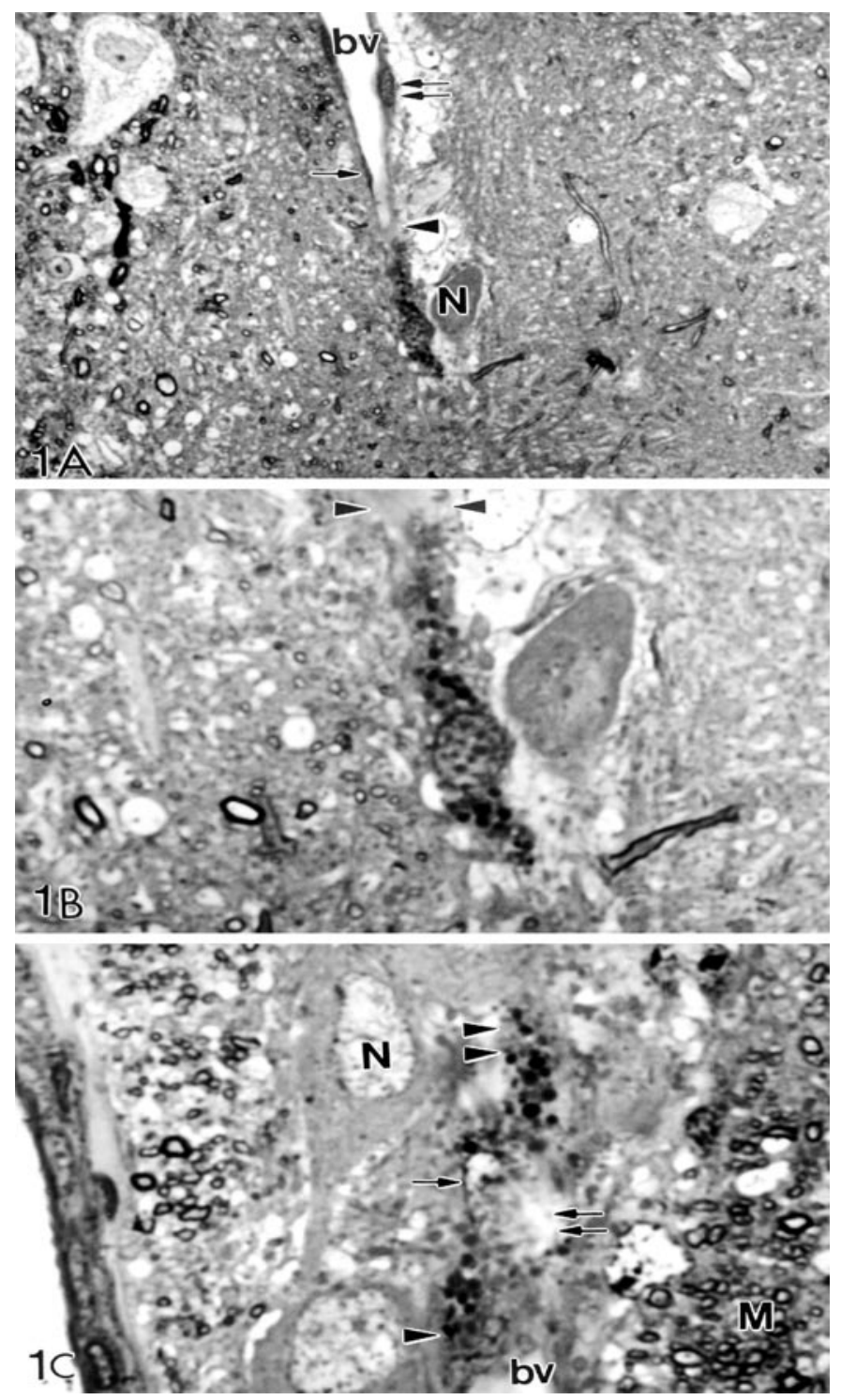

Figure 1. Sections $(1 \mu \mathrm{m})$ through two mast cells from a non-injected, postpartum female. $A$, Low magnification photomicrograph showing the location of an elongated, granulated MC (arrowhead) and a thin-walled blood vessel $(b v)$. The single arrow indicates the nucleus of the endothelial cell, the double arrows indicate the nucleus of the pericyte, and the single arrowhead indicates the region where the MC is in close contact with the basal lamina of the blood vessel. A neuron $(N)$ is shown adjacent to the MC. Magnification, $850 \times . B$, A higher magnification of the same MC as in $A$. The elongate shape of the MC is associated with migration. The two arrowheads indicate the boundaries of basal lamina of the blood vessel. The trailing end of the MC is just external to the basal lamina. Magnification, $1900 \times$. C, Another example of an MC with one end (arrowhead) adjacent to a blood vessel $(b v)$ and the opposite pole stretching into the neuropil (double arrowheads). The single arrow indicates the position of a portion of the MC nucleus, whereas the double arrows indicate a glancing section through the nucleus of a neuron that is outside of the plane of focus. $N$ is a neuron near the MC process. $M$, Myelinated axon bundles. Magnification, $1900 \times$.

marks). Both host and donor MCs were in the same optical plane (data not shown). For the two animals in which density gradient centrifugation was used to purify the $\mathrm{MCs}$, the percentage that were double-labeled (Fig. $3 B-D$ ) was determined; double-labeled cells accounted for 2.3 and $4.9 \%$. For the four animals in which immunoselection was performed followed by $24 \mathrm{hr}$ in culture, the 

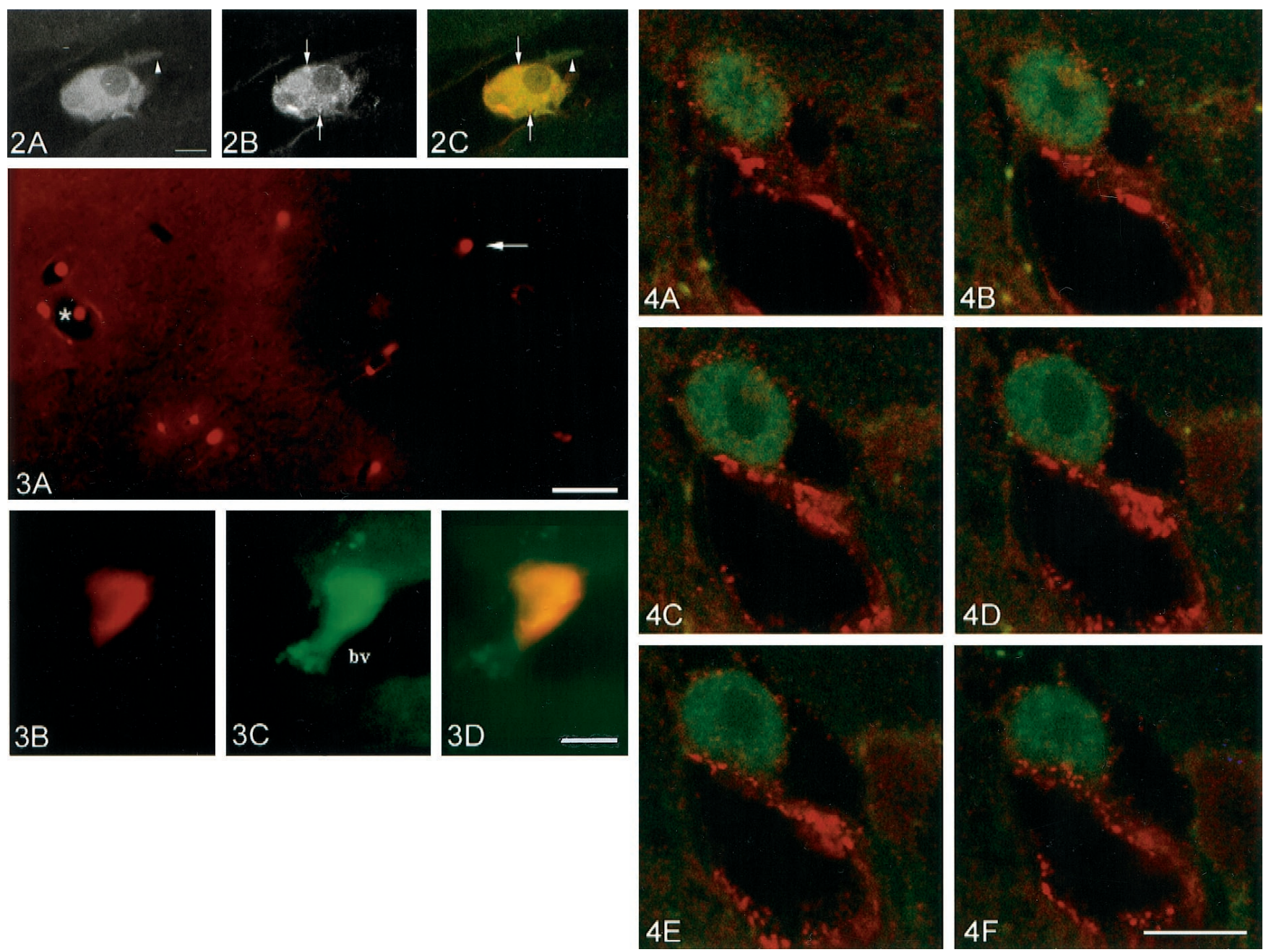

Figure 2. Single $1 \mu \mathrm{m}$ optical section through a CTG-positive mast cell $(A)$ that contains serotonin $(B)$. The overlay $(C)$ shows that the two fluorophores are in the same cell. Small cellular processes are evident in this cell $(A, C$, arrowhead), and serotonergic granules or clusters of granules can be seen in $B$ and $C$ (arrows). Scale bar, $5 \mu \mathrm{m}$.

Figure 3. Low $(A)$ and high $(B-D)$ magnification conventional fluorescence photomicrographs showing the distribution of 5HT-positive mast cells $(A)$ in the rat dorsolateral thalamus. MCs are distributed throughout the tissue and cluster around large blood vessels (asterisk). The arrow indicates the double-labeled cell shown in $B-D$. $B$ shows the serotonin immunoreactivity, $C$ shows the fluorescence of CTG, and in $D$ the two channels are overlaid. Note that the serotonin staining $(B)$ is more concentrated in one pole of the cell, whereas the CTG $(C)$ is evenly distributed throughout the cytoplasm. The extended processes on the lower aspect of the MC are characteristic of migrating cells. Scale bars: $A, 25 \mu \mathrm{m} ; B-D, 5 \mu \mathrm{m}$.

Figure 4. Serial $1 \mu \mathrm{m}$ optical sections through a donor MC labeled with CTG. Factor VIII immunofluorescence (red) marks the endothelial basal lamina. The Factor VIII is deposited in large puncta. In $B$ and $C$, the right-hand edge of the MC is apparently in contact with the basal lamina, as indicated by the overlay of red and green. The remainder of the cell $(A, D-F)$ is on the brain side of the extracellular matrix. Scale bar, $10 \mu \mathrm{m}$.

percentage of donor cells was higher, with a mean of $12 \%$ (range 7-20\%).

\section{Location of donor cells and components of the blood-brain barrier}

All of the following experiments were performed with CTG as the vital dye. Figure 4 is a series of sequential $1 \mu \mathrm{m}$ optical sections through a mast cell (marked with the vital dye) and the endothelial basal lamina (identified immunocytochemically by the localization of Factor VIII) (Fig. $4 A-F$ ). In this representative example, the majority of the $\mathrm{MC}$ is adjacent to tissue devoid of Factor VIII, i.e., free of the endothelial basal lamina.

To extend these observations, tissue sections were incubated in an antiserum to GFAP, which demarcates the cell layer beyond the endothelium. As seen in Figure 5, a computed depth projection, GFAP processes form a basket or network around the large blood vessel and a portion of the dye-filled MCs is in the neuropil internal to the astrocyte processes.

\section{DISCUSSION}

This study represents the first experimental demonstration of mature MCs entering the normal adult CNS via a vascular route. This discovery is particularly significant in that the donor MCs crossed the blood-brain barrier quickly. This time frame is consistent with the rate of increase of mature MC numbers in the adult dove brain after pairing (Silver et al., 1992; Zhuang et al., 1993; Silverman et al., 1994) and could account for the increased number of MCs in the thalamus reported here for postpartum rats. Thus mature MCs, like other immune system cells (Williams and Hickey, 1995), can traffic through the CNS (see below). The capacity of MCs to traverse brain blood vessels is not an artifact 

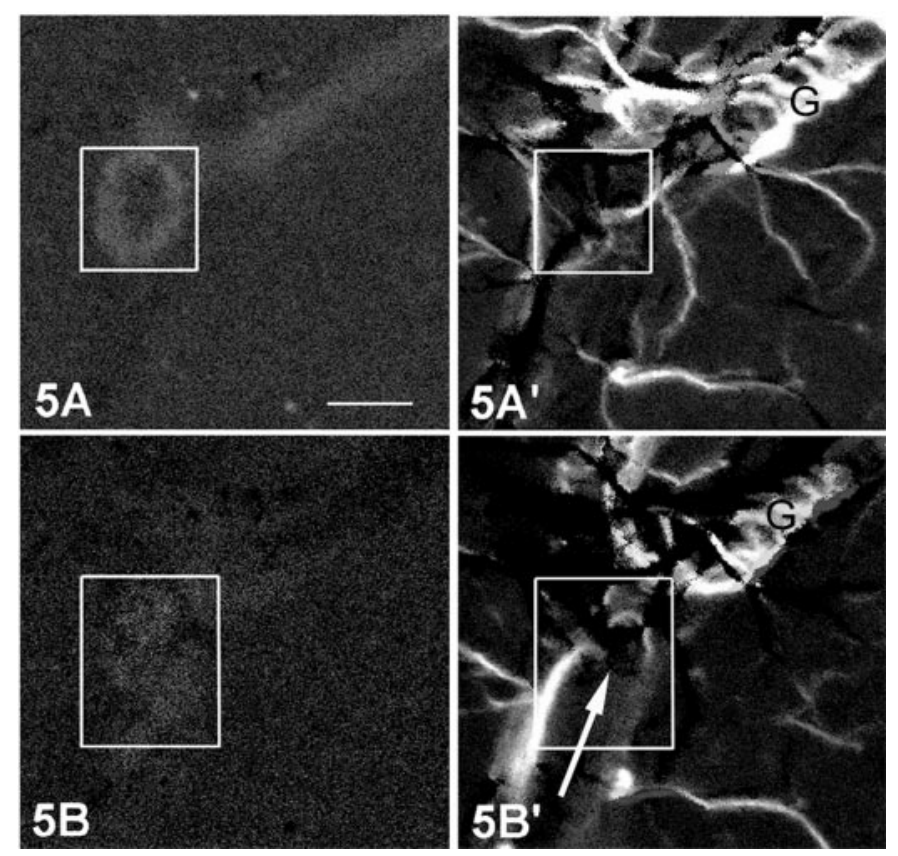

Figure 5. A depth projection of an MC marked by CTG $(A, B)$ and astrocytes marked immunocytochemically by glial fibrillary acidic protein $\left(A^{\prime}, B^{\prime}\right)$. These are two levels through an MC that are compilations of the middle $\left(A, A^{\prime}\right)$ and lower third of the cell $\left(B, B^{\prime}\right)$, each micrograph representing $\sim 3 \mu \mathrm{m}$ of depth. The lumen of the blood vessel associated with the glial ensheathment ( $G$, thick processes) is below this optical plane. The box in $A$ contains the MC; the same box in $A^{\prime}$ is devoid of thick glial process, indicating that the MC lies above the ensheathment and is in the neuropil. In $B$, the CTG signal has almost disappeared, indicating that there is very little of the MC cytoplasm remaining (box). At this level $\left(B^{\prime}\right)$, one can see the basal lamina of the blood vessel and the glial ensheathment $(G)$. The arrow lies on the basal lamina and indicates the trajectory of the blood vessel. Scale bar, $5 \mu \mathrm{m}$.

of the injection protocol because similar images were also seen in noninjected controls (compare Figs. 1, 3).

It was important for this study to use mature cells so that we could assess their retention of migratory capacity. Donor cells were judged to be mature before injection because (1) the density gradient isolation procedure used selects against immature cells that lack their full complement of granules (Purcell et al., 1989); (2) the cells analyzed from the final pellet contained numerous metachromatic and predominately safranin-positive granules (Enerback et al., 1986); (3) the cells had abundant histamine or serotonin (Enerback et al., 1986) (depending on which was tested) when found in the host brain; and (4) in $1 \mu \mathrm{m}$ sections the cytoplasm was filled with granules. Serial section reconstructions revealed an oval nucleus within each of the donor cells, the regular nuclear outline suggesting that the cells were healthy at the time of vascular perfusion and not undergoing apoptosis.

We have shown that donor MCs penetrate the CNS rather than remaining adherent to the plasma side of the blood vessel wall. This was best demonstrated in the double-stained combinations that used the vital dye and immunocytochemistry for Factor V III and GFAP to reveal the endothelial basal lamina or astrocytic processes, respectively. The MCs were clearly past the basal lamina as defined by the Factor VIII marker distribution. In both confocal and DIC images (data not shown), the MCs lay in a "cup" with the astrocyte processes forming the base. Previous electron microscopic studies showed that MCs in the adult mammalian brain are internal to the endothelium and its basal lamina.
Some of the MC volume is in contact with surrounding astrocyte processes whereas the remaining volume of the cell contacts the neuropil (Ibrahim et al., 1979; Dimitriadou et al., 1990; Manning et al., 1994) (present data). In the present experiments, host MCs were lined up along the same blood vessel with the donor cells and in the same confocal plane. Taken together, these data support the conclusion that donor MCs had crossed the bloodbrain barrier.

The communication between the CNS and the immune system is bidirectional. For example, immune reactions can be conditioned (MacQueen et al., 1989; Ader et al., 1990; Djuric and Bienenstrock, 1993). In addition, cellular elements of the immune system migrate across the blood-brain barrier. Activated mature T lymphocytes cross into the CNS; when they do not encounter properly presented antigen, they return to the circulation (Hickey et al., 1991), with a transit time (in and out) of 9-12 hr. More recently it has been shown that activated $B$ cells and natural killer cells can also enter the brain (Williams and Hickey, 1995). Thus, the brain is under immune surveillance, and more importantly in the present context, mature MCs can now be added to the list of cell types that penetrate the adult CNS from the circulation.

It is possible that the donor MCs are in an activated state and/or come in contact with brain tissue made accessible by the physiological state of the host. MCs in reproductive organs are altered in their distribution and activity in differing gonadal steroid states (Brandon and Evans, 1983; Padilla et al., 1990). In this study we showed that there were more MCs in the thalamus of the postpartum animals compared with virgin animals. This situation is analogous to the rise in MC number in a specific brain region (medial habenula) during courtship (Zhuang et al., 1993) and after gonadal steroid treatment (Wilhelm, King, Silverman, Silver, unpublished observations). We have also shown that treatment with gonadal steroids can result in MC degranulation (Silver et al., 1996; Wilhelm, King, Silverman, Silver, unpublished observations).

It is also possible that the isolation procedures activate MCs. Both protocols are designed to produce MCs that will respond subsequently to physiological stimuli and in most experiments includes an MC stabilizing agent, wortmannin, to prevent or limit degranulation before the final wash and injection. Because most (donor) peritoneal MCs have IgE bound on their surface, they could on injection become activated by either IgE-dependent or -independent mechanisms. Histochemistry before injection (see Materials and Methods) and immunocytochemistry afterward show that both donor and host MCs are filled with secretory granules, suggesting that activation (degranulation) had been limited. These latter statements are true for both isolation procedures.

The mechanism whereby the MCs transit the brain capillary endothelium and its basal lamina is not known. Angiogenic factors do stimulate mast cell migration in the periphery (Gruber et al., 1995). MCs, like T cells, express integrin pairs LPAM-1 and -2, which are associated with T cell homing (Gurish et al., 1992). MCs, like other immune cells, can adhere to endothelia and exhibit rolling behavior in a P-selectin-dependent manner (Sriramarao et al., 1996), the first step to diapedesis for other hematopoietic cells. MCs also contain many proteases (Woodbury et al., 1989; Goldstein and Wintroub, 1993), which are released in a regulated manner (Kolset and Gallagher, 1990). These enzymes could create a pathway through the endothelial junctions and the extracellular matrix of the basal lamina. The ability of peripheral mast cells to migrate from a connective tissue stroma across a 
basement membrane to gain access to the epithelium has been noted (Morales et al., 1980).

Evidence from in vitro experiments demonstrates that both quiescent and activated MCs can attach and/or move across various substrata (Thompson et al., 1990, 1991, 1993; Bianchine et al., 1992; Thompson and Metcalfe, 1993; Metcalfe, 1995). One permissive substrate is laminin, for which MCs have the appropriate receptors (Thompson et al., 1991). Laminin is found in the basal lamina of brain endothelial cells and can be produced by astrocytes (Liesi, 1985). Glial cells could promote further mast cell movement by secreting matrix molecules (Meyer-Puttlitz et al., 1996) or by the expression of chemotaxic factors such as TGF- $\beta 1$ (da Cunha and Vitkovic, 1992) or IL-3 (Frei et al., 1985; Farrar et al., 1989). Finally, resident MCs can recruit other MCs by secreting ATP (Osipchuk and Cahalan, 1992). The latter possibility provides a self-regulatory mechanism for the attraction and movement of these multifunctional cells.

\section{REFERENCES}

Abercrombie M (1946) Estimation of nuclear population from microtomic sections. Anat Rec 94:239-247.

Ader R, Felten DL, Cohen N (1990) Interactions between the brain and the immune system. Annu Rev Pharmacol Toxicol 30:561-602.

Airaksinen MS, Panula P (1988) The histaminergic system in the guinea pig central nervous system: an immunocytochemical mapping study using an antiserum against histamine. J Comp Neurol 273:163-186.

Bacallao R, Kiai K, Jesaitis L (1995) Guiding principles in specimen preservation for confocal microscopy. In: Handbook of biological confocal microscopy (Pawley JB, ed), pp 311-326. New York: Plenum.

Bacci S, Arbi-Riccardi R, Mayer B, Rumio C, Borghi-Cirri MB (1994) Localization of nitric oxide synthetase immunoreactivity in mast cells of human nasal mucosa. Histochemistry 102:89-92.

Bankl HC, Radaszkiewicz T, Klappacher GW, Glogar D, Sperr WR, Grosschmidt K, Lechner K, Valent P (1995) Increase and redistribution of cardiac mast cells in auricular thrombosis. Possible role for kit ligand. Circulation 91:275-283.

Bianchine PJ, Burd PR, Metcalfe DD (1992) IL-3-dependent mast cells attach to plate-bound vitronectin. Demonstration of augmented proliferation in response to signals transduced via cell surface vitronectin receptors. J Immunol 149:3665-3671.

Brandon JM, Evans JE (1983) Changes in uterine mast cells during the estrous cycle in the Syrian hamster. Am J Anat 167:241-247.

Brosnan CF, Claudio L, Tansey FA, Martiney J (1990) Mechanisms of autoimmune neuropathies. Ann Neurol 27:S75-79.

Buma P, Roubos EW (1986) Ultrastructural demonstration of nonsynaptic release sites in the CNS of the snail, Lymnaea stagnalis, the insect, Periplaneta americana, and the rat. Neuroscience 17:867-879.

Cocchiara R, Albeggiani G, Lampiasi N, Boniovanni A, Azzolina A, Geraci D (1999) Histamine and tumor necrosis factor alpha production from purified rat brain mast cells mediated by substance P. NeuroReport 10:575-583.

Coggeshall RE, Lekan HA (1996) Methods for determining numbers of cells and synapses: a case for more uniform standards of review. J Comp Neurol [Erratum (1996) 369:162] 364:6-15.

Cutz E, Chan W, Track NS, Goth A, Said SI (1978) Release of VIP in mast cells by histamine liberators. Nature 275:661-662.

da Cunha A, Vitkovic L (1992) Transforming growth factor-beta 1 (TGF- $\beta 1$ ) expression and regulation in rat cortical astrocytes. J Neuroimmunol 36:157-169.

Dimitriadou V, Lambracht-Hall M, Reichler J, Theoharides TC (1990) Histochemical and ultrastructural characteristics of rat brain perivascular mast cells stimulated with compound 48/80 and carbachol. Neuroscience 39:209-224.

Djuric VJ, Bienenstrock J (1993) Learned sensitivity. Ann Allergy $71: 5-14$.

Dropp JJ (1972) Mast cells in the central nervous system of several rodents. Anat Rec 174:227-238.

Dropp JJ (1976) Mast cells in mammalian brain. Acta Anat 94:1-21.

Enerback L, Miller HRP, Mayrhofer G (1986) Methods for the identification and characterization of mast cells by light microscopy. In: Mast cell differentiation and heterogeneity (Befus AD, Bienenstock J, Denburg JA, eds), pp 405-417. New York: Raven.

Farrar WL, Vinocour M, Hill JM (1989) In situ hybridization histochemistry localization of interleukin-3 mRNA in mouse brain. Blood 73:137-140.

Frei K, Bodmer S, Schuerde C, Fontana A (1985) Astrocytes of the brain synthesize interleukin-3 like factors. J Immunol 135:4044-4047.

Flood PR, Kruger PG (1970) Fine structure of mast cells in the central nervous system of the hedgehog. Acta Anat 75:443-452.

Galli SJ, Wershil BK, Gordon JR, Tsai M, Hammel I (1993) Insight into mast cell development and function derived from analyses of mice carrying mutations at beige, W/c-kit, or SI/SCF (c-kit ligand) loci. In: The mast cell in health and disease (Marcel M, Kaliner A, Metcalfe DD, eds), pp 109-128. New York: Marcel Dekker.

Gill CJ, Rissman EF (1998) Mast cells in the neonate musk shrew: implications for neuroendocrine immune interactions. Brain Res Dev Brain Res 111:129-136.

Goldschmidt RC, Hough LB, Glick SD (1985) Rat brain mast cells: contribution to brain histamine levels. J Neurochem 44:1943-1947.

Goldstein SM, Wintroub BU (1993) Mast cell proteases. In: The mast cell in health and disease (Kaliner MA, Metcalfe DD, eds), pp 343380. New York: Marcel Dekker.

Gruber BL, Kaplan AP (1993) Mast cells and rheumatic disease, Ed 12 (McCarty DJ, Koopman WJ, eds), pp 5860-5867. Philadelphia: Lea and Febiger.

Gruber BL, Marchese MJ, Kew RR (1994) Transforming growth factor- $\beta 1$ mediates mast cell chemotaxis. J Immunol 152:5860-5867.

Gruber BL, Marchese MJ, Kew RR (1995) Angiogenic factors stimulate mast cell migration. Blood 86:2488-2493.

Guo Z, Turner C, Castle D (1998) Relocation of the t-SNARE SNAP-23 from lamellopodia-like cell surface projections regulates compound exocytosis in mast cells. Cell 94:537-548.

Gurish MF, Bell AF, Smith TJ, Ducharme LA, Wang RW, Weis JH (1992) Expression of murine $\beta 7, \alpha 4$ and $\beta 1$ integrin genes by rodent mast cells. J Immunol 149:1964-1972.

Hebda PA, Collins MA, Tharp MD (1993) Mast cell and myofibroblast in wound healing. Dermatol Clin 11:685-696.

Hickey WF, Hsu BL, Kimura H (1991) T-lymphocyte entry into the central nervous system. J Neurosci Res 28:254-260.

Ibrahim MZM (1974) The mast cells of the mammalian central nervous system. I. Morphology, distribution, and histochemistry. J Neurol Sci 21:431-478.

Ibrahim MZM, Al-Wirr ME, Bahuth N (1979) The mast cells of the mammalian central nervous system. III. Ultrastructural characteristics in the adult rat brain. Acta Anat 104:134-154.

Johnson D, Seeldrayers PA, Weiner HL (1988) The role of mast cells in demyelination. 1. Myelin proteins are degraded by mast cell proteases and myelin basic protein and P2 can stimulate mast cell degranulation. Brain Res 444:195-198.

Kaminer MS, Murphey GF, Zweiman B, Lavker RM (1995) Connective tissue mast cells exhibit time-dependent degranulation heterogeneity. Clin Diagn Lab Immunol 2:297-301.

Katayama N, Shih JP, Nishikawa SI, Kina T, Clark SC, Ogawa M (1993) Stage specific expression of c-kit protein by murine hematopoietic progenitors. Blood 82:2353-2360.

Kaufman RJ, Wasley LC, Dorner AJ (1988) Synthesis, processing and secretion of recombinant human factor VIII expressed in mammalian cells. J Biol Chem 263:6352-6362.

Kitamura Y, Kasugai T, Arizono N, Matsuda H (1993) Development of mast cells and basophils: processes and regulation mechanisms. Am J Med Sci 306:185-191.

Kolset SO, Gallagher JT (1990) Proteoglycans in haematoapoietic cells. Biochim Biophys Acta 1032:191-211.

Lambracht-Hall M, Dimitriadou V, Theoharides TC (1990) Migration of mast cells in the developing rat brain. Brain Res Dev Brain Res. 56:151-159.

Leon A, Buriani A, Dal Toso R, Fabris M, Romanello S, Aloe L, Levi-Montalcini R (1994) Mast cells synthesize, store, and release nerve growth factor. Proc Natl Acad Sci USA 91:3739-3743.

Levi-Schaffer F, Shalit M (1989) Differential release of histamine and prostaglandin D2 in rat peritoneal mast cells activated with peptides. Int Arch Allergy Appl Immunol 90:352-357.

Liesi P (1985) Laminin-immunoreactive glia distinguish regenerative adult CNS systems from non-regenerative ones. EMBO J 4:2505-2511.

MacQueen G, Marshall J, Perdue M, Siegel S, Bienenstock J (1989) 
Pavlovian conditioning of rat mucosal mast cells to secrete rat mast cell protease II. Science 243:83-85.

Manning KA, Pienkowski TP, Uhlrich DJ (1994) Histaminergic and non-histamine-immunoreactive mast cells within the cat lateral geniculate complex examined with light and electron microscopy. Neuroscience 63:191-206.

Marquardt L, Alongi JL, Walker LL (1996) The phosphatidylinositol 3-kinase inhibitor wortmannin blocks mast cell exocytosis but not IL-6 production. J Immunol 156:1942-1945.

Marshall JS, Gauldie J, Nielson L, Bienenstock J (1993) Leukemia inhibitory factor production by rat mast cells. Eur $\mathrm{J}$ Immunol 23:2116-2120.

Metcalfe DD (1995) Interaction of mast cells with extracellular matrix proteins. Int Arch Allergy Immunol 107:60-62.

Meyer-Puttlitz B, Junker E, Margolis RU, Margolis RK (1996) Chondroitin sulfate proteoglycans in the developing CNS. II. Immunocytochemical localization of neurocan and phosphacan. J Comp Neurol 366:44-54.

Miyagami M, Smith BH, McKeever PE, Chronwall BM, Greenwood MA, Kornblith PL (1987) Immunocytochemical localization of Factor VIII-related antigen in tumors of the human central nervous system. J Neurooncol 4:269-285.

Morales CR, Pereyra LA, Toledo OMS, Montes GS (1980) Histochemical and morphological characterization of migrating mast cells. Histochemistry 68:159-168.

Neumann J (1890) Über das Vorkommen der sogenannten "Mastzellen" bei pathologischen Veranderungen des Gehirns. Virchows Arch Pathol Anat 122:378-380.

Osipchuk Y, Cahalan M (1992) Cell-to-cell spread of calcium signals mediated by ATP receptors in mast cells. Nature 359:241-244.

Padilla L, Reinicke K, Montesino H, Villena F, Asencio H, Cruz M, Rudolph MI (1990) Histamine content and mast cells distribution in mouse uterus: the effect of sexual hormones, gestation and labor. Cell Mol Biol 36:93-100.

Persinger MA (1983) Degranulation of brain mast cells in young albino rats. Behav Neural Biol 39:299-306.

Powell HC, Braheny SL, Myers RR, Rodriguez M, Lampert PW (1983) Early changes in experimental allergic neuritis. Lab Invest 48:332-338.

Purcell WM, Cohen DL, Hanahoe THP (1989) Contribution of postsecretory mechanisms to the observed pattern of histamine and 5HT secretion from peritoneal mast cells in response to compound 48/80. Int Arch Allergy Appl Immunol 90:387-394.

Rodewald HR, Dessing M, Dvorak AM, Galli SJ (1996) Identification of a committed precursor for the mast cell lineage. Science 271:818-822.

Salvemini D, Masini E, Anggard E, Mannaioni P, Vane J (1990) Synthesis of a nitric oxide-like factor from 1-arginine by rat serosal mast cells. Biophys Biochem Res Commun 169:596-601.

Seeldrayers PA, Yasui D, Weinter H L, Johnson D (1989) Treatment of experimental allergic neuritis with nedocromil sodium. J Neuroimmunol 25:221-226.

Silver R, Ramos CL, Silverman AJ (1992) Sexual behavior triggers the appearance of non-neuronal cells containing gonadotropin-releasing hormone-like immunoreactivity. J Neuroendocrinol 4:207-210.

Silver R, Silverman AJ, Vitkovic L, Lederhendler I (1996) Mast cells in the brain: evidence and functional significance. Trends Neurosci 19:25-31.

Silverman AJ, Millar RP, King JA, Zhuang X, Silver R (1994) Mast cells with gonadotropin-releasing hormone-like immunoreactivity in the brain of doves. Proc Natl Acad Sci USA 91:3695-3699.

Sriramarao P, Anderson W, Wolitzky BA, Broide DH (1996) Mouse bone marrow-derived mast cells roll on P-selectin under conditions of flow in vivo. Lab Invest 74:634-643.
Sutherland RJ (1982) The dorsal diencephalic conduction system: a review of the anatomy and functions of the habenular complex. Neurosci Biobehav Rev 6:1-13.

Theoharides TC (1990) Mast cells: the immune gate to the brain. Life Sci 46:607-617.

Theoharides TC, Baloyannis SJ, Yanolidis LS (1991) Activated rat peritoneal mast cells can cause syngeneic brain demyelination in vitro. Int J Immunopathol Pharmacol 4:137-144.

Theoharides T, Spanos C, Pang X, Alferes L, Ligris K, Letourneau R, Rozniecki JJ, Webster E, Chrousos GP (1995) Stress-induced intracranial mast cell degranulation: a corticotropin-releasing hormonemediated effect. Endocrinology 136:5745-5750.

Thompson HL, Metcalfe DD (1993) Adhesion receptors and their relevance to the biology of mast cells and basophils. In: The mast cell in health and disease (Kaliner MA, Metcalfe DD, eds), pp 763-799. New York: Marcel Dekker.

Thompson HL, Burbelo PD, Metcalfe DD (1990) Regulation of adhesion of mouse bone marrow-derived mast cells to laminin. J Immunol 145:3425-3431.

Thompson HL, Burbelo PD, Yamada Y, Kleinman HK, Metcalfe DD (1991) Identification of an amino acid sequence in the laminin A chain mediating mast cell attachment and spreading. Immunology 72:144-149.

Thompson HL, Thomas L, Metcalfe DD (1993) Murine mast cells attach to and migrate on laminin, fibronectin, and matrigel-coated surfaces in response to Fc epsilon RI-mediated signals. Clin Exp Allergy 23:270-275.

Tsai MS, Newlands GF, Takeishi T, Langley KE, Zsebo KM, Miller HR, Geissler EN, Galli SJ (1991) The rat c-kit ligand, stem cell factor, induces the development of connective tissue-type and mucosal mast cells in vivo. Analysis by anatomical distribution, histochemistry, and protease phenotype. J Exp Med 174:125-131.

Undem B, Riccio M, Weinreich D, Ellis J, Myers A (1995) Neurophysiology of mast cell-nerve interactions in the airways. Int Arch Allergy Immunol 107:199-201.

Urade Y, Ujihara M, Horiguchi Y, Igarashi M, Magata A, Ikai K, Hayaishi O (1990) Mast cells contain spleen-type prostaglandin D synthetase. J Biol Chem 265:371-375.

Weinrich D, Moore KA, Taylor GE (1997) Allergic inflammation in isolated vagal sensory ganglia unmasks silent NK-2 tachykinin receptors. J Neurosci 17:7683-7693.

West MJ, Slomianka L, Gundersen HJ (1991) Unbiased stereological estimation of the total number of neurons in the subdivisions of the rat hippocampus using the optical fractionator. Anat Rec 231:482-497.

Williams KC, Hickey WF (1995) Traffic of hematogenous cells through the central nervous system. Curr Top Microbiol Immunol 202:221-245.

Woodbury RG, Le Trong H, Cole K, Neurath H, Miller HRP (1989) Rat mast cell proteases. In: Mast cells and basophil differentiation and function in health and disease (Galli SJ, Austen KF eds), pp 71-79. New York: Raven.

Yano H, Wershil BK, Arizono N, Galli SJ (1989) Substance P-induced augmentation of cutaneous vascular permeability and granulocyte infiltration on mice is mast cell dependent. J Clin Invest 84:1276-1286.

Zhuang X, Silverman AJ, Silver R (1993) Reproductive behavior, endocrine state, and the distribution of GnRH-like immunoreactive mast cells in dove brains. Horm Behav 27:283-295.

Zhuang X, Silverman AJ, Silver R (1996) Brain mast cell degranulation regulates the blood brain barrier. J Neurobiol 31:393-403.

Zhuang X, Silverman AJ, Silver R (1999) Distribution and local differentiation of mast cells in the parenchyma of the forebrain. J Comp Neurol 408:477-488. 